\title{
Market and marketing within the concept of functioning and development of cultural heritage sites
}

\author{
Andrzej Szromnik
}

\begin{abstract}
A B S T R A C T
Objective: The article presents the conditions, factors, and stages of development of the market orientation of cultural heritage objects. The author introduced a terminological distinction - the cultural potential of the object and its market potential. The market potential is understood as the ability to generate revenues from commercial activities (products and services).

Research Design \& Methods: The conceptual nature of the article determined the scope of methods used in diagnosing, analyzing, and synthesizing the phenomena and processes discussed. These were primarily critical literature studies, which usually limited considerations of the market role of cultural heritage objects to the cases of museum institutions and their tourist functions.
\end{abstract}

Findings: Developing and organizing knowledge about the market concept of the functioning of cultural heritage objects, as well as indicating the main directions in the strategic marketing management of these objects. Besides, the paper points out the relationship between the cultural potential and market potential of historic buildings and outlines its significance.

Contribution \& Value Added: The presented concept of market orientation of cultural heritage objects breaks with the narrow understanding of the market of these objects and its only marginal role in generating development factors. The sustainable development of historic buildings should be focused on a balance between its functional goals (protection and conservation), socio-civilization goals, and economic ones.

\begin{tabular}{ll}
\hline Article type: & research paper \\
& cultural heritage; heritage marketing; heritage industry; heritage \\
Keywords: & tourism; marketing of museum; market orientation of culture; eco- \\
& nomic of culture
\end{tabular}

JEL codes: M31, M38, R53, Z13, Z33

\section{Suggested citation:}

Szromnik, A. (2019). Market and marketing within the concept of functioning and development of cultural heritage sites. International Entrepreneurship Review (previously published as International Entrepreneurship / Przedsiębiorczość Międzynarodowa, 5(3), 79-94. https://doi.org/10.15678/IER.2019.0503.06 


\section{INTRODUCTION}

In a market economy, every organization, regardless of its founding statute, enters into various relationships with other entities in horizontal or vertical system structures. The first type of structure mainly includes market relations, reflecting the totality of relationships with suppliers of goods and services, on top of relationships with customers: consumers, users, agents, or co-operators. This applies not only to commercial organizations, but also to many non-profit organizations focused on on-financial, socially useful purposes, not involving economic value creation.

Many groups of non-profit entities sector, more often called the civil sector, includes a subgroup of quasi-non-profit organizations, which in addition to broadly understood social goals, successfully pursue parallel or secondary objectives by entering in numerous and varied market relationships characteristic for purchase and sales transactions. Likewise, independently and on their own account, they make and offer their own products. Thus achieved revenues increase the amount of their social power resources necessary for their functioning. This type of institutions includes historic buildings and their complexes, which, due to their importance for the identity of nations and ethnic-regional groups possess valuable, unique and symbolic qualities are referred to as cultural heritage sites.

Cultural heritage sites in general and using some simplification will be referred to herein as historic buildings, historic property or historic building complexes. Although their activities are funded from the budget of the central, departmental, and local government, they supplement their finances with their own revenue streams. This is the result of a creative and rational approach to the overarching and priority social and civilization objectives. It also stems from searching and determining a functional compromise, meaning, a broad understanding of the goals and social mission assigned to cultural heritage sites.

The acceptance of the priority and superiority of social goals, in the practice of cultural heritage sites, does not prevent them from an appropriate orientation towards the efficiency of services and the use of held human, tangible, and intangible resources. It is thanks to an extended operational program, thanks to incorporation of new areas of activity, that additional opportunities open up to improve their economic and financial situation. It all comes down to proper interpretation of mission and strategic objectives in the functioning of cultural heritage sites, and in fact is necessary to reorient their management and other staff.

The aim of this study is to present and clarify the conditions, possibilities and forms of the market operation concept of historic buildings. The category of "market potential" of an object is introduced, confronted and compared with its cultural potential. On this basis, a simple cycle changes model from cultural potential to the market development potential was worked out. The provided block diagram mapping the marketing steps to reorient the object of cultural heritage is proposed as a general model. The creation and the implementation of value exchange (usability, satisfaction) between the object and its customers (stakeholders) is a basis of the marketing management philosophy.

This study presents conceptual and theoretical considerations, explaining a breakthrough moment not only in the functional transformations of historic sites, but also many other institutions of culture. Observing the sector market transformations taking place here 
leads to the conclusion that this is a response to the new and wider perception of such places and their role in society as well as economy. The presented generalizations, proposals and conclusions are a voice in the scientific debate about the scope of market relations in culture and in this particular segment thereof: the material, architectural heritage.

\section{LITERATURE REVIEW}

The mainstream considered herein is related to the marketing perspective of cultural heritage, and therefore, its possibilities and the conditions of applying marketing in the implementation of current and prospective objectives of their activities in a particular social, economic, legal and natural environment. The marketing concept of managing that specific cultural resource as the management of an institution with a unique mission in society derives from the area of cultural economics, the economics of cultural goods also known as the economics of cultural heritage. They assume the perception and treatment of historical sites as entities of the contemporary market of goods and services as entities oriented towards a specified range of profit, revenue generation and excess allowing them to limit the costs of their operation to some extent (Barański, 2016; Ilczuk, 2012; Jung, 2011; Kopeć, 2016; Throsby, 2010; Murzyn-Kupisz, 2010; Murzyn-Kupisz, 2016; Towse, 2011).

Pointing to the desirability of market restructuring of cultural heritage, the need to change their organizational and functional concept, and as a result, reorientation of their program offers, is not a new approach. Marketing and appropriate marketing strategies in the business of historic buildings have been discussed by the authors of many scientific publications indicating and specifying details of the marketing way of thinking and acting that would be appropriate to the specific characteristics, position and resources of these entities,. From a chronological perspective, works of Thornburg (1986), Dominquez (1986), Herbert, Prentice, and Thomas (1989) are noteworthy.

In the Polish marketing literature, the first papers devoted to marketing in the cultural sector were authored by the Wroclaw authors from the then University of Economics (now the University of Economics), namely, the monographs edited by Knecht, Styś (1990) and Mazurek-Łopacińska (1997). The Wroclaw stream also includes a book by Sobocińska (2015). Marketing in relation to the operation and management of cultural institutions was the subject of monographs of many other Polish authors, including Niemczyk (2007), Wróblewski (2012), Łodziany-Grabowska and Wiktor (2014). This group should also include the monographic study of foreign authors (translated into Polish) by Dragicevic-Šečič and Stojković (2010). All the listed authors treated the cultural sector narrowly, along with its subject structure, functional features and potential marketing strategies. Indeed, they focused on cultural institutions such as theaters, operas, cinemas, concert halls, cultural centers and art galleries. The few cases of reference and practical accounts regarded objects of cultural heritage as market wholes, as an integrated concept of cultural chattel and properties with the corresponding special events, the involved artists and designers (Smoleń, 2013). Another point of view was adopted in the monograph by Parowicz, Who considered the marketing of cultural heritage, on the basis of conservation services (Parowicz, 2019).

Sites of cultural heritage - historic buildings, architectural and environmental complexes, and the most valuable historic properties were not previously subject to comprehen- 
sive and relevant conceptual considerations or design work discussing their marketing strategies in a systematic and complete manner, together with the relevant instruments and techniques of market stimulation. These objects are usually seen as centers of cultural tourism, and thus their marketing studies analysis focused on tourist services: product concepts, pricing instrument structure, the promotion of these services and the ways of distributing them, and target marketing offers. Tourist point of view in the discussion of marketing is visible in studies: Chhabra (2010), Fullerton, McGettingan, Stephens (2010).

A functional approach, proper for examining the activities of historic buildings from the perspective of the leading narrowly understood function is a hallmark of many monographs in the field of marketing cultural heritage sites. Their authors examine objects such as museums. In this way their market activities boil down to a supply of paid museum services. Without questioning the legitimacy and the need of seeing the museum as a specific "enterprise" or more generally a "market entity" one cannot, however, equal the marketing of cultural heritage sites and museum marketing. This is due to the obvious fact that not every museum is a museum of historic interiors. Many of them are located in modern premises that do not meet the criterion of "historicity". It is the items displayed there for the public are have the historic character and value. Despite this limitation, some monographs dedicated to the "museum heritage" and services associated with it are noteworthy Kowalczyk (1995), McLean (1997), Simm (2006), and also Matt (2006); Kotler et al. (2008); Montemaggi and Severino (2007), French and Runyard (2011), on top of one by Sparr which treats the problems of social responsibility and sustainable functioning of cultural heritage (Starr, 2013).

A wide perspective on "heritage marketing" is offered by the unique monograph by Misiura (2006). On its 280 pages, the author explains and develops a marketing concept of the functioning of the "heritage industry" (heritage industry), discussing, among other issues, the essence of heritage marketing, market segmentation, the marketing mix concept (in relation to the markets of tourist services, and the food and beverage industry), in addition to preparing marketing campaigns. Despite the lack of direct reference to the marketing strategies of cultural heritage sites, Misiuna's work deserves high appreciation and recognition for its leadership in this area in the marketing literature.

Marketing of cultural heritage in many cases is considered as closely connected with place marketing" known in the Polish literature as urban and regional marketing, or location marketing. This is evidenced not only by the work of Napolitano and De Nisco (2017), but also, and perhaps above all, by the Third. Caribbean International Conference on "Heritage - Tourism and Hospitality" (2014), during which Govers gave an introductory speech on "The Role of Heritage in Place Marketing and Branding."

In addition to these published texts, the issue of cultural heritage marketing can be found in teaching-oriented projects. "Marketing of Heritage sites" was taught, among others, by Cenderello (2015) in the framework of the European "Lifelong Learning Program" project, which was a HISA (Heritage Interpretation for Senior Audiences) project in Italy. It should also be emphasized that the subject matter has been included in a postgraduate studies project under the name of "Heritage Academy" initiated and successfully implemented in Krakow by the International Cultural Center and the Malopolska School of Public Administration at the Cracow University of Economics for years. 


\section{MATERIAL AND METHODS}

\section{Cultural potential and market potential of an object of cultural heritage}

In above deliberations, historic buildings and their eligibility for the special group of historic sites, cultural heritage was considered according to a definition, due to their high qualities and their importance for future generations. Therefore, their artistic, social and civilization-building value was taken into account and evaluated. Such a view and classification of these objects can be called passive qualification, because it omits important operating parameters: functionals, which determine the real potential of cultural heritage to generate income streams market. Examination of a site from the point of view of its condition, value and importance as a "legacy of former generations" (passive perspective) should be replaced by an assessment of its capacities and opportunities to meet current human needs in terms of learning about the past, gaining knowledge of communities forever lost, and their characteristics, everyday life, habits, skills, preferences, aspirations and other activities. The transition from passive description and the treatment of cultural heritage sites to active characterization, stressing the "dormant" possibilities in the historic site requires an introduction of the concept of "cultural potential". This term refers to a particular site and determines its active cultural, active, possible operating resource for practical use. The existence of a valuable site is one thing, but its ability to meet the constantly changing human needs, wants and expectations which are not always fully known, is another. This means that it might be the case that the site of high cultural value has a limited or even mediocre cultural potential. Qualities and their possession are important, but more so is the social use of the values, and their transformation into a useful resource for development.

Own external offer

Offering paid services

Knowledge of the market - customers

Knowledge of the competitors

Orientation on own resources

Market operation strategy

Efficiency orientation

Openness to change

Priority for clients' needs and desires

Partnership network

Figure 1. Historical object on the market (10 functional features) Source: own elaboration.

Examination of the potential of a cultural heritage site requires the broadening of the spectrum of the social value assessment. The aforementioned characterized system of three features, that is, artistic value, historical value and emotional value is therefore proposed to be extended by further two criteria of scientific and technological value. In the first case, the importance and usefulness of the site for science, or in fact, for scientific disciplines and the 
concrete benefits resulting from this for the scientific cognition, depending on the formulation and claims. The scientific value of a site might me due to its uniqueness, particular nature of its functions, design, technology, materials used or use (Fig. 2).

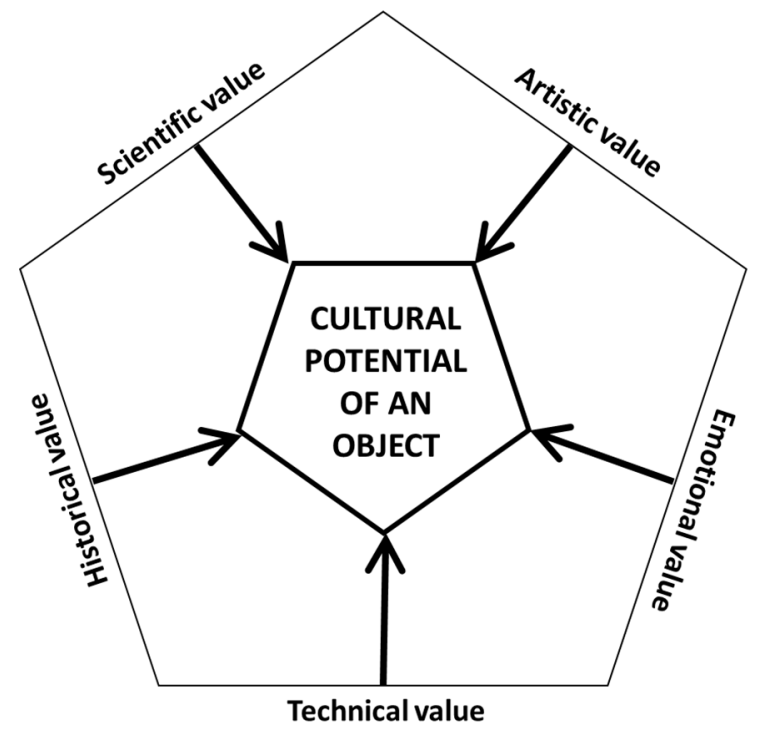

Figure 2. Cultural potential of a cultural heritage object and it's main ingredients Source: own elaboration.

An important feature of a cultural heritage site determining its cultural potential is its technological value. It is determined by the condition of the site, the degree of destruction of its elements, the durability and the similarity to the original state. The technical condition may be perfect, corresponding to the original, but also very poor, even completely in ruins. There are, of course, certain relations between the introduced traits, as the technological value affects the historical and artistic ones to some.

The potential of a cultural heritage site in its operational, active interpretation influences another, akin characteristic, namely its potential utility. This, in turn, determines the market potential of the site, understood as the ability to generate the expected market flows: operating income due to marketing of its material resources (movable and immovable goods, objects and human resources, durable and non-durable assets).

Taking into account and ordering all the introduced categories into a logical sequence: cultural potential (initial state), utility potential and market potential, one can determine the final category, that is, the development potential of the institution of a historic building as an independent market entity. Thanks to a high market potential, new development opportunities arise. Increased revenues are the source of purchases, rents, hires of additional service-making factors, which in turn allow the entity to develop, expand and improve its offer profile and to market specific products. In this way, the cycle of changes in the cultural heritage site has been specified, as a cyclic, repetitive mechanism of interconnection between the potential characteristics of a historical site (Fig. 3). 


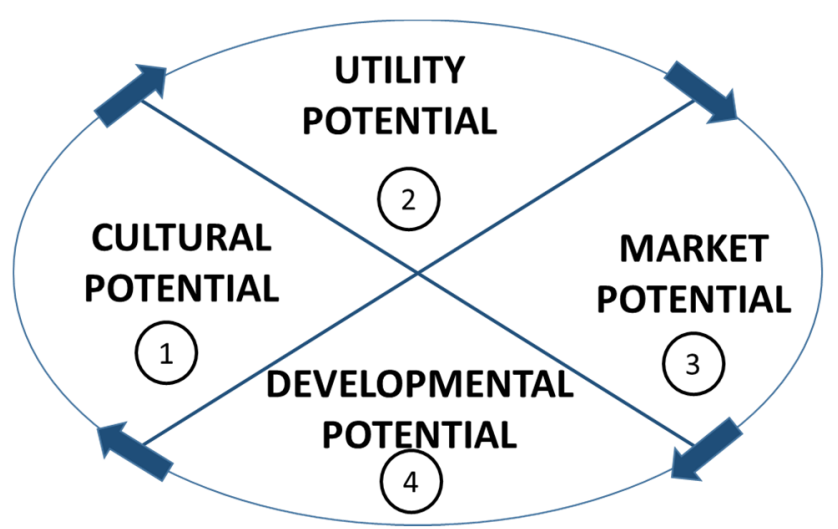

Figure 3. Development cycle - changes of cultural heritage object Source: own elaboration.

In the mechanism of the development of cultural heritage, the relationship between cultural potential and market potential has a key importance. It defines the relationship and the corresponding interactions of the two main characteristics of the site. To explain and clarify the signaled cause-and-effect relationship more precisely one needs to identify the most important particular factors that contribute to the enlargement or reduction of the market potential of a historic site with a particular cultural potential. Thus, for each site, eight traits that affect its marketing potential are proposed, wherein a + (plus) indicates a factor contributing to an increase in the capacity, and the - (minus) sign, a respectively negative market potential factor. Therefore, the following stimulants and destimulants of market potential in historical sites have been adopted:

- (+) location relative (to a large city, in a neighborhood, populated areas),

- (+) accessibility by transport,

- (-) costs of adaptation, building repairs,

- (-) operating costs,

- (-) scope of conservation,

- (-) ownership claims (unspecified legal status),

- (+) attractive natural surroundings,

- (+) complex social relations (local, regional, national, international).

Thus compiled list of determinants of the market potential of a historic building is certainly not a closed one. It was deliberately brought down to the principal factors, even if ignoring other factors of organizational, technical, economic (price conditions for making the site available to the public) and marketing nature (Fig. 4).

Two features considered, "culture potential" and "market potential" are in a directly proportional relationship, which is equivalent to the thesis that a high cultural potential of a property and its growth can stimulate the growth of this potential and its further increase. However, it is not always so, which is impacted e.g. by the previously considered factors and circumstances. Selection of cultural potential (one dimension of the matrix) with a market potential (second dimension of the matrix) enables four output solutions: four strategic positions of a historic building (each feature has two states, i.e., a high and low status). 


\section{MARKET POTENTIAL}

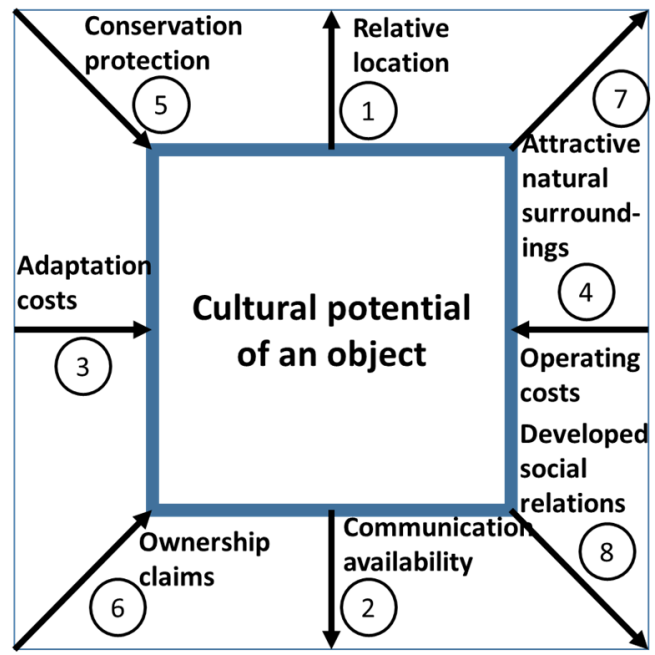

Figure 4. From cultural potential to market potential Source: own elaboration.

In situation 1: the position can be described as a "golden goose with the golden eggs" (a combination of: large cultural potential and a large market potential).

In situation 2: the position can be called a "golden cage" (a combination of large cultural potential and small market potential).

In situation 3: the position can be referred to as a "chance of success" (combination: small cultural potential and large market potential).

In situation 4: the position is defined as "harsh reality" (a combination of small cultural potential and small market potential).

The extracted starting strategic positions of a cultural heritage site will help explain the initial conditions for the concept of functioning of sites with different resources and capabilities. The chances of success for sites of with particularly unfavorable combinations of resources are related to the capabilities of status changes from "low" to "high", in the case of both considered potential indicators. If increasing of cultural potential of a historic site is limited, or in fact impossible, it is the right direction to improve the situation and prospects of growth by increasingly orienting to the market and increasing the market potential of the historic building (Fig. 5).

\section{Cultural potential and market potential of an object of cultural heritage}

Market opening of historic buildings which boils down to a conscious, deliberate and systematic, and above all, paid, sharing of resources and opportunities to interested individuals and institutions is associated with the gradual changing of the general concept of the facility's operation. This change does not imply, however, replacing the social and civilization-making 


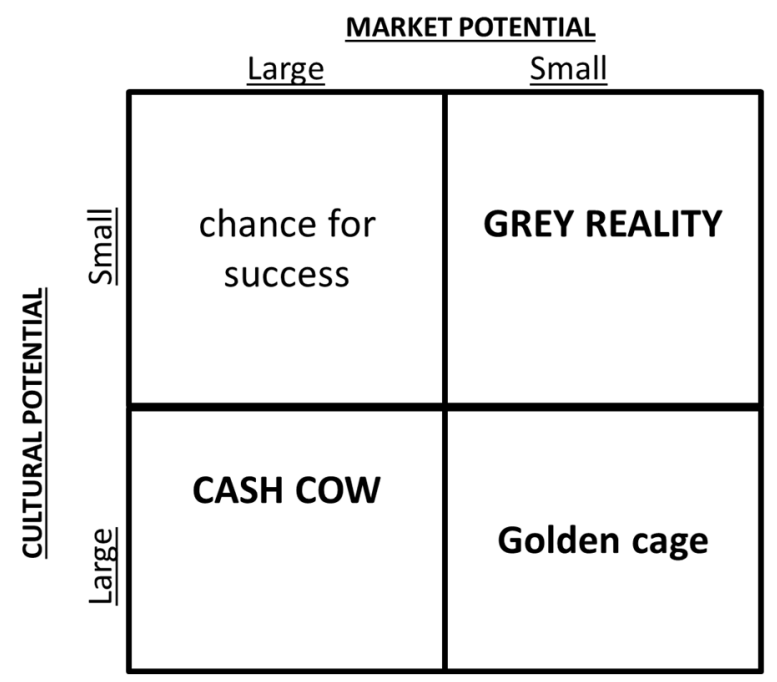

Figure 5. Cultural potential vs. market potential of cultural heritage objects - table of strategic positions Source: own elaboration.

concept with the concept of a commercial orientation. This would be tantamount to a revolutionary change of a complete change of the goals and ways of achieving them, organizational, material, and also mental changes for the entire staff.

The new orientation - towards the market - should complement the main one, always leading orientation towards society and civilization. It was this direction, after all, that defines and clarifies the meaning of the protection and preservation of tangible and intangible heritage of past generations for the future. A gradual and moderate, properly balanced marketing of heritage sites, its scope, forms and the specific conditions should, as it is assumed, support and strengthen the culture-making mission of heritage sites.

Market-oriented functional changes should be recommended as gradual, evolutionary changes, at every assessment of broadly defined results and expenditures, without bringing this relationship only to a simple economic calculation. In practice, this means the preparation and implementation of experimental activities, activities performed "on trial", allowing for an analysis and evaluation only, to make the necessary adjustments as a new (paid) offer for the stakeholders.

The whole of the market changes, which in this place can be called marketing changes, can be organized in chronological order with the appropriate separation of six states. These states reflect the effects of widening and deepening the market profile of a cultural heritage site, i.e., the effects of the adoption of marketing as a site management concept (Cf. Fig. 6).

As an initial state of an aspiring market reorienting entity, an "orientation towards legal resources" has been adopted. It corresponds to a set of record-ordering actions, as a result of which the possible resources will be identified and adopted, primarily for formal reasons, and their marketization to use the market offers proposals for potential 
clients. The preliminary activities explicitly limit the possible, due to conservation, technical and organizational reasons, whether the site is made available as a whole, or only separated parts of it, or groups of historic items found there (e.g. furnishing, exhibitions, special collections, etc.). The analysis, evaluation and simulations conducted under this stage may eliminate or limit the scope of the market use of the historic building, bringing it to a margin of all activities implemented.

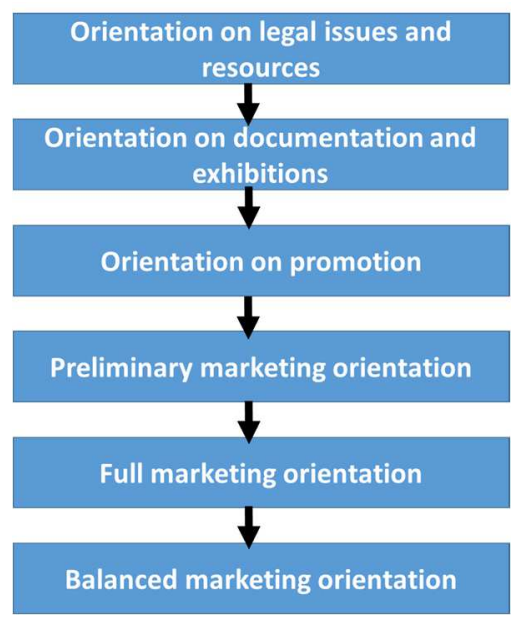

Figure 6. Six phases of market orientation development of a cultural heritage object Source: own elaboration.

The logical order of market-oriented changes lead to isolating a second, also preparatory step, which was appropriately named "documentary and display orientation". It involves the development of documentation and information on resources intended for commercial use, and as a result, the creation of historical information resources as an important component of the prospective exhibitions, which is a crucial component in building the attractiveness of the market offer. Exposition preparation of periodic or permanent display is the primary direction and a form of sharing historic buildings. The proper market offer comes down to viewing exhibits and interiors in combination with learning about their characteristics, functions, users and makers. The information provided, together with feelings, sensations and evaluations created, make up the market advantages of the exhibition offer.

Preparation of the historic building and the corresponding expositions to explore does not guarantee a good frequency of visits and a resulting financial profit. To a large extent, this depends on the rightly directed, convincing and attractive promotion of the project. This boils down to a broad, mass and accurate communication of the project to potential stakeholders based on the involvement of popular media. This stage in the gradual commercialization of cultural heritage, according to its essence, is referred to as the promotional orientation stage. Dissemination of information to promote a historical site, encouraging visiting, renting or leasing or even purchasing part or all of it is expressed by an appropriate marketing approach to the management of this particular cultural resource in a market economy. 
Active, professional market communication does not mean the right marketing orientation of the historic building yet. This stage is reached when the main reference point for the market projects is the potential customer whose needs and desires in terms of knowledge and experiences, sensations and feelings are the basis of the arrangement of the exhibition, the individual rooms and the equipment of the historic building.

The marketing concept of cultural heritage site functioning mainly corresponds to mental changes in the staff, including managers and owners of the site. They should recognize and accept the priority of the market - the subordination of the functional concept of the entity to the requirements and expectations of customers and the whole market environment. A proper, full marketing orientation of historical sites as institutional monuments of culture is already the fifth stage of their respective evolutionary change is constituted by the requirements of the modern times, which is a condition for the smooth functioning and development based largely on the use and sharing of resources.

The last stage in the procedure of the proposed evolutionary reorientation of cultural heritage sites is a phase of changes, the last stage called "sustainable marketing orientation". It is an operating concept of historical sites which implies a purposeful compromise, balancing the main operational objectives, which is the appropriate relationship of the three groups of purposes: to protect and conserve, to build civilization and society, and to maintain economic and financial balance. Such a balance expresses a correct, appropriate, adequate to the possibilities and expectations of society, distribution of activities and priorities. Any deviation from the point (area) signifying the equality of the objectives indicates a preferential dominance of one of these objectives and the associated degradation of the others. In this way, one can identify and group cultural heritage sites, which are clearly oriented towards one of the following functional purposes and those whose activities are close to a compromise in their aspirations, preferences and priorities (Fig. 7).

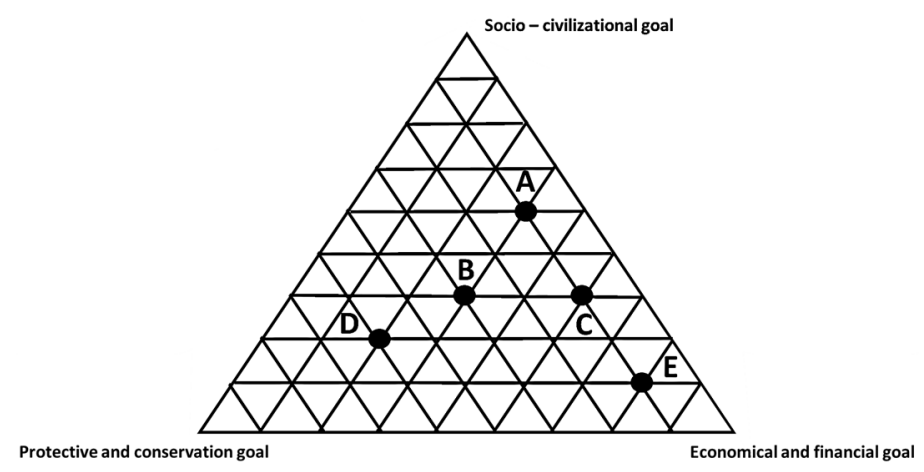

Figure 7. Triangle of balanced functioning of a cultural heritage object (Presentation of different variants of the distribution of goals) Source: own elaboration.

The market orientation of cultural heritage sites corresponds to the concept of a consistent focus on the present and future needs and desires of customers (visitors, participants, tenants, and future owners). It is its characteristic idea for the product offer along with the conditions and terms of making it available to the public. Marketing and consequent orientation is also a way of market-oriented thinking of all the staff, accepting the customers and 
financial revenues flowing from their use as an important source of development throughout the organization. The marketing orientation does not dictate the historic sites what to do in an administrative top-down way. It is the result of searching for new development opportunities, and possibilities to gain important additional benefits in its immediate environment.

\section{Value replacement as the basis of the marketing concept of cultural heritage sites}

The marketing way of thinking and entrepreneurial action can be considered in relation to both the business of human activity, and projects of a social nature as opposed to profitoriented. It assumes, however, the existence of relationships of exchange between entities (partners, collaborators, parties in court cases) where each offers a package of marketing values of major importance for each recipient. Bi-directional flow of value streams (benefits, utility, satisfaction) connects the sender of value with its recipient. This means that each entity receives a significant value, but also passes some value to the partner of exchange (Fig.8).

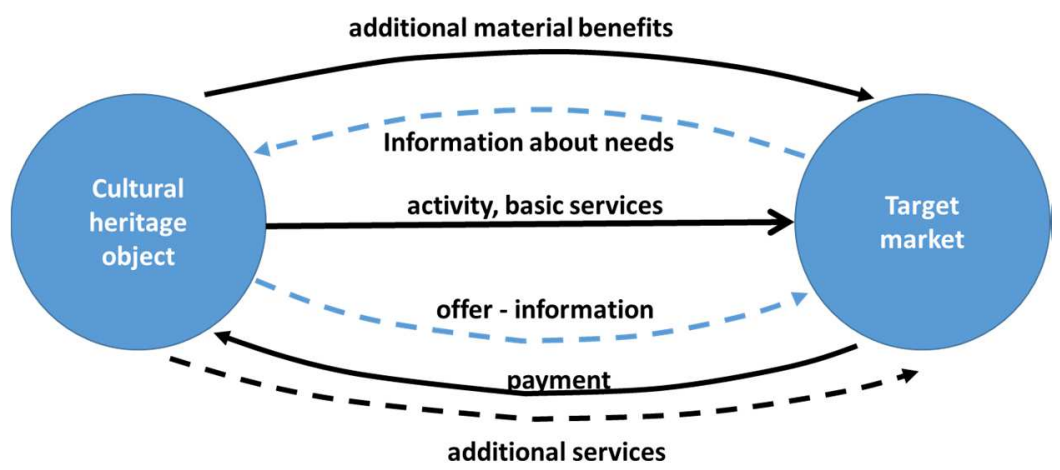

Figure 8. Basic diagram of marketing value exchange Source: own elaboration.

Media marketing value carriers being exchanged are usually tangible goods and cash. Increasingly, however, exchanged values arise from the provision of services to one's partner, information provided to them and ideas submitted. The most important matter is the right choice of benefits available for a fee, partially payable or free, or such values, goods, services, ideas, information or places that will be highly appreciated by the customers and will bring them maximum satisfaction. Organization's marketing staff track record priorities, expectations and opinions of market operators, in order to propose the most effective and satisfying combinations of the offered securities on their basis.

Sites of cultural heritage that adopt and adapt a system of marketing thinking and acting shape a set of values appropriate for their own resources, capabilities and operational objectives to be provided to their partners. They are primarily guided by the needs and wants of their partners previously identified. The basic scheme of marketing value exchange involving historic buildings does not, therefore, differ from the general scheme of market exchange.

The main value created and made available through the heritage site to its customers and partners is clear and is connected with the activity, utility, and the main services provided by it. The value of the basic service, that is, enabling the customer to get acquainted 
with the presented exhibition, is complemented by accompanying additional services of a different nature, together with a set of historical information. The scope of services results from prior identification of the needs, expectations and interests of the main groups of recipients. Thus, the supplied set of intellectual (sensations, impressions, experiences), but also utilitarian values (transportation, food, accommodation, entertainment, training) is exchanged for money (payment) and a number of emotional values such as appreciation, praise, feedback and own assessment.

The bi-directional flow of value (benefits) as a condition of the marketing approach, allows them to balance them and compare their importance to consumers. Thanks to this specific balance, a subjectively understood resulting surplus or deficit in the values for each of the parties to the transaction of exchange is made possible. In the first case (excess value), it generates corresponding satisfaction and its intensity, and in the second case, absence thereof and the accompanying disappointment and disapproval of the value exchange.

To sum up this part of the considerations, it should be stressed that the marketing approach to the operation and development of cultural heritage is based on precise and systematic recognition, creation and anticipation of the needs and desires of customers and partners, which results in acquiring information used for the shaping of market-accepted proposals regarding the main products.

\section{CONCLUSIONS}

The market orientation of cultural heritage sites, due to external and internal conditions of this process, is a complex and multi-faceted endeavor, and it is also difficult from the organizational, legal and mental point of view. The particular importance of this process and its crucial meaning for the organization had already been indicated in the pioneering work of Murzyn-Kupisz (2010).

Treating a cultural heritage site as a modern market entity generates the question of how to "marketize" the functioning of such organizations. It is a question on the nature and purpose of changing the philosophy of historic buildings. Defining a universal program of investigation to fully open up the entities in question to the market is not easy, it is not possible to be implemented directly and does not guarantee the final success of the respective project. Therefore, intending to even outline and to indicate some degree of generalization of a functional program of restructuring, a model is introduced that is recommendable to many other entities introducing a formula for the market as a strategic priority.

The model program of cultural heritage market reorientation provides for the implementation of several pilot and preparatory projects, namely:

- a precondition to convince the entire management team of the cultural heritage site to the idea of the market restructuring through discussion, simulation, and providing examples of opportunities and threats in the "new reality",

- transformation program expanding functional priorities that should be disseminated among all groups of employees in the form of direct messages, websites and synthetic written communication,

- a detailed scenario for the development of the necessary changes, modifications and operational corrections, as well as their implementation in practice; establishment of a 
Restructuring Team composed of representatives of all groups of employees. The proposed measures should have a directional executive power across the facility,

- preparation and completion of economic, managerial and marketing training program is recommended in terms of content tailored to the needs and qualifications of employees,

- in a situation of educational and management resources' shortage, it is recommended to seek advice of external specialists - experts and consultants in the field of culture, economics, and marketing services.

The implementation of the signalled preparatory program will facilitate the mental and operational change of options to the functioning of the cultural heritage site. In the end, a lack of contradiction between the "traditional" concept and the market concept of the activities will be revealed. The process of market restructuring of historic buildings can be implemented gradually, taking into account the identified stages of development based on the criterion of minimizing the social and financial costs of the necessary reforms.

\section{REFERENCES}

Barański, R. (2016). Finansowanie działalności kulturalnej. Warszawa: C.H.Beck.

Chhabra, D. (2010). Sustainable marketing of cultural and heritage tourism. London-New York: Routledge.

Cenderello, A. (2015). Marketing of heritage sites. Received from http://www.interpret-europe.net/fileadmin/Documents/projects/HISA/HISA_Marketing_Heritage_sites.pdf in May, 2019

Dominguez, V.R. (1986). The Marketing of Heritage. Journal of the American Ethnological Society, 13 (3), 546-555.

Dragičevič-Šečič, M. \& Stojkovič, B. (2010). Kultura: zarzq̨dzanie, animacja, marketing. Warszawa: NCK.

Jung, B. (Ed.) (2011). Ekonomika kultury. Od teorii do praktyki. Warszawa: NCK, Instytut Adama Mickiewicza.

French, Y., \& Runyard, S. (2011). Marketing and Public Relations for museums, galleries, cultural and heritage attractions. London-New York: Routledge.

Fullerton, L., McGettigan, K. \& Stephens, S. (2010). Integrating management and marketing strategies at heritage sites. International Journal of Culture, Tourism and Hospitality Research, 4(2), 108-117.

Herbert, D.T., Prentice, R.T., \& Thomas, C.J. (1989). Heritage sites: strategies for marketing and development. Aldershot, Hants: Avebury.

Ilczuk, D. (2012). Ekonomika kultury. Warszawa: Wydawnictwo Naukowe PWN.

Łodziana-Grabowska, J., \& Wiktor, J.W. (Eds.) (2014). Koncepcje zarzqdzania i marke-tingu w sferze kultury - projektowanie, implementacja i kontekst skuteczności działań. Warszawa: CeDeWu.

Knecht, Z., \& Styś A. (Eds.) (1990). Marketing w działalności instytucji i jednostek upowszechniania kultury. Warszawa: Wydawnictwo Spółdzielcze.

Kopeć, K.D. (2014). Finansowanie kultury w ramach społecznej odpowiedzialności biznesu. Kraków: LIBRON.

Kotler, N.G., Kotler, Ph., \& Kotler, W.I. (2008). Museum Marketing and Strategy. Desining, Missions, Building Audiences, Generating Revenue and Resources. San Francisco: Jossey Bass.

Kowalczyk, W. (1995). Marketing w muzeum. Muzealnictwo, 37, 10-20.

Matt, G. (2006). Muzeum jako przedsiębiorstwo. Łatwo i przystępnie o zarzq̨dzaniu instytucjq kultury. Warszawa: Fundacja Aletheia. 
Mazurek-Łopacińska, K. (Ed.) (1997). Kultura w gospodarce rynkowej - problemy adaptacji marketingu. Warszawa-Wrocław: AE Wrocław.

Mc Lean, F. (1997). Marketing the museum. London-New York: Routledge.

Misiura, S. (2006). Heritage Marketing. Oxford: ELSEVIER Ltd.

Montemaggi, M., \& Severino, F. (2007). Heritage Marketing - La storia Dell' Impresa Italiana come vantaggio competitive. Milano: Franco Angeli.

Murzyn-Kupisz, M. (2010). Barbarzyńca w ogrodzie? Dziedzictwo kulturowe widziane z perspektywy ekonomii. Zarzqdzanie Publiczne, 13(3), 19-32.

Murzyn-Kupisz M. (2016). Instytucje muzealne z perspektywy ekonomii kultury. Kraków: Universitas.

Napolitano, M.R., \& De Nisco, A. (2017). Cultural heritage: the missing "link" in the place marketing literature "chain". Place Branding and Public Diplomacy, 13(2), 101-106.

Niemczyk, A. (2007). Marketing w sferze kultury - wybrane problemy. Kraków: AE Kraków.

Parowicz, I. (2019). Cultural Heritage Marketing. A Relationship Marketing Approach to Conservation Services. London: Palgreve Pivot.

Parsons, E. (2008). Non-profit Marketing. New York: SAGE Publications Ltd.

Simm, C. (2006). Besucherorientiertes Museumsmarketing - Hintergmende und Finanzierung. Saarbrücken: VDM Verlag Dr. Müller.

Smoleń, T. (2013). Marketing w tworzeniu wartości dla klienta na rynku dóbr kultury - na przykładzie oferty muzeum. Handel Wewnętrzny, t. I, ed. spec., 263-269.

Sobocińska, M. (2015). Uwarunkowania i perspektywy rozwoju orientacji rynkowej w podmiotach sfery kultury. Wrocław: UE Wrocław.

Starr, F. (2013). Corporate responsibility for cultural heritage: conservation sustainable development and corporate reputation. New York-London. Routledge.

Thorburg, A. (1986). Marketing cultural heritage. Does it work within Europe?. Travel \& Tourism Analyst, December, 39-48.

Throsby, D. (2010). Ekonomia i kultura. Warszawa: NCK.

Towse, R. (2011). Ekonomia kultury. Kompendium. Warszawa: NCK.

Wróblewski, Ł. (2012). Strategie marketingowe w instytucjach kultury. Warszawa: PWE. 


\section{Author}

\section{Andrzej Szromnik}

Full Professor at the University of Economics in Krakow and the State University of Technology and Economics in Jarosław. Dr hab. economic sciences in the field of management. Areas of scientific, research and teaching interest - Place Marketing, Marketing Research, Management of Retailing, Marketing Management. Lecturer at the Academy of Heritage - Cultural Heritage PostGraduate Program (International Center of Culture in Krakow).

Correspondence to: Prof. Andrzej Szromnik PhD, Cracow University of Economics, ul. Rakowicka 27, 31-510 Kraków, Poland, e-mail: szromnia@uek.krakow.pl

ORCID (1) http://orcid.org/0000-0003-2494-0753

\section{Acknowledgements and Financial Disclosure}

The article was financed by the subsidy granted to the Cracow University of Economics. The author would like to thank the anonymous referees for their useful comments, which allowed to increase the value of this article.

\section{Copyright and License}

This article is published under the terms of the Creative Commons

Attribution - NoDerivs (CC BY-ND 4.0) License

http://creativecommons.org/licenses/by-nd/4.0/

Published by the Centre for Strategic and International Entrepreneurship - Krakow, Poland 